\title{
Diagnosis of Breakthrough Fungal Infections in the Clinical Mycology Laboratory: An ECMM Consensus Statement
}

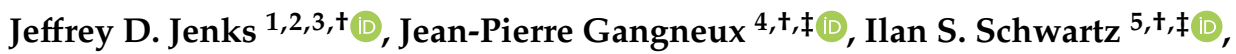 \\ Ana Alastruey-Izquierdo ${ }^{6, t, \neq} \neq$, Katrien Lagrou ${ }^{7,8, t, \ddagger}$, George R. Thompson III ${ }^{9,+}$,

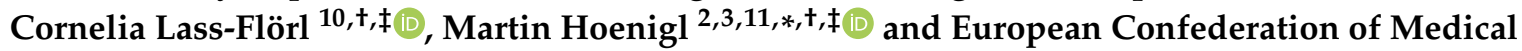 \\ Mycology (ECMM) Council Investigators $\ddagger$
}

1 Division of General Internal Medicine, Department of Medicine, University of California San Diego, San Diego, CA 92103, USA; jjenks@ucsd.edu

2 Division of Infectious Diseases and Global Public Health, Department of Medicine, University of California San Diego, San Diego, CA 92103, USA

3 Clinical and Translational Fungal-Working Group, University of California San Diego, La Jolla, CA 92093, USA

4 Univ Rennes, CHU Rennes, Inserm, EHESP, Irset (Institut de Recherche en Santé, Environnement et Travail)_UMR_S 1085, F-35000 Rennes, France; jean-pierre.gangneux@univ-rennes1.fr

5 Division of Infectious Diseases, Department of Medicine, Faculty of Medicine and Dentistry, University of Alberta, Edmonton, AB T6G 2R3, Canada; ilan@ualberta.ca

6 Mycology Reference Laboratory, National Centre for Microbiology, Instituto de Salud Carlos III. Majadahonda, 28222 Madrid, Spain; anaalastruey@isciii.es

7 Department of Microbiology, Immunology and Transplantation, KU Leuven, 3000 Leuven, Belgium; katrien.lagrou@uzleuven.be

8 National Reference Centre for Mycosis, Department of Laboratory Medicine, University Hospitals Leuven, 3000 Leuven, Belgium

9 Division of Infectious Diseases, Department of Internal Medicine and Department of Medical Microbiology and Immunology, UC-Davis Medical Center, Sacramento, CA 95817, USA; grthompson@ucdavis.edu

10 Division of Hygiene and Medical Microbiology, Medical University of Innsbruck, 6020 Innsbruck, Austria; cornelia.lass-floerl@i-med.ac.at

11 Section of Infectious Diseases and Tropical Medicine, Department of Internal Medicine, Medical University of Graz, 8036 Graz, Austria

* Correspondence: mhoenigl@ucsd.edu; Tel.: +1-619-543-5605

+ These authors contributed equally to this work.

$\ddagger$ ECMM Council Investigators: Z. Adamski, S. Arikan-Akdagli, V. Arsic-Arsenijevic, O.A. Cornely, N. Friberg, N. Gow, S. Hadina, P. Hamal, M. Juerna-Ellam, N. Klimko, L. Klingspor, F. Lamoth, M. Mares, T. Matos, V. Ozenci, T. Papp, E. Roilides, R. Sabino, E. Segal, A.F. Talento, A.M. Tortorano, P. Verweij.

Received: 1 September 2020; Accepted: 7 October 2020; Published: 11 October 2020

\begin{abstract}
Breakthrough invasive fungal infections (bIFI) cause significant morbidity and mortality. Their diagnosis can be challenging due to reduced sensitivity to conventional culture techniques, serologic tests, and PCR-based assays in patients undergoing antifungal therapy, and their diagnosis can be delayed contributing to poor patient outcomes. In this review, we provide consensus recommendations on behalf of the European Confederation for Medical Mycology (ECMM) for the diagnosis of bIFI caused by invasive yeasts, molds, and endemic mycoses, to guide diagnostic efforts in patients receiving antifungals and support the design of future clinical trials in the field of clinical mycology. The cornerstone of lab-based diagnosis of breakthrough infections for yeast and endemic mycoses remain conventional culture, to accurately identify the causative pathogen and allow for antifungal susceptibility testing. The impact of non-culture-based methods are not well-studied for the definite diagnosis of breakthrough invasive yeast infections. Non-culture-based methods have an important role for the diagnosis of breakthrough invasive mold infections, in particular invasive
\end{abstract}


aspergillosis, and a combination of testing involving conventional culture, antigen-based assays, and PCR-based assays should be considered. Multiple diagnostic modalities, including histopathology, culture, antibody, and/or antigen tests and occasionally PCR-based assays may be required to diagnose breakthrough endemic mycoses. A need exists for diagnostic tests that are effective, simple, cheap, and rapid to enable the diagnosis of bIFI in patients taking antifungals.

Keywords: breakthrough invasive fungal infections; invasive candidiasis; invasive mold infections; endemic mycoses; diagnostics

\section{Introduction}

Invasive fungal infections (IFIs) cause significant morbidity and mortality, particularly in patients with compromised immune systems, such as patients with underlying hematologic malignancies, hematopoietic stem cell transplant recipients (HSCT), solid organ transplant (SOT) recipients, and others who are critically ill in intensive care units (ICUs). In many of these patients, antifungal prophylaxis and/or early empirical treatment are used during the greatest period of risk for IFI to decrease morbidity and mortality from these infections. Still, some patients will develop a breakthrough IFI (bIFI) [1,2], defined as any IFI that occurs during adequate exposure to an antifungal agent, including from fungi outside the spectrum of activity of the antifungal agent, as recently defined in detail by the European Confederation for Medical Mycology (ECMM) and Mycoses Study Group Education and Research Consortium (MSGERC) consensus criteria [3]. Of note, initial improvement of clinical, radiological or mycological signs of IFI is an added requirement to differentiate breakthrough IFI from refractory IFI in those receiving targeted or pre-emptive therapy [3].

The diagnosis of bIFI can be challenging. Overall, while they remain the cornerstone of IFI diagnostics, culture-based approaches are limited by low sensitivity in patients exposed to antifungals, and delays in diagnosis are common [4]. In addition, conventional biomarkers that have become the mainstay of diagnosis of IFIs and specifically on invasive aspergillosis, such as $1,3-\beta$-d-glucan (BDG) and galactomannan (GM), respectively, are negatively influenced in patients receiving mold-active prophylaxis or treatment [5-9].

Here, we review the literature on the diagnosis of bIFI, including conventional diagnostics such as culture, serologic tests, nucleic-acid based assays, and other modalities for the diagnosis of bIFI from both yeasts and molds. Lastly, we provide consensus recommendations on behalf of the ECMM.

\section{Materials and Methods}

Executives of the ECMM selected a group of authors based on content expertise, including individuals involved with the ECMM either as council members, fellows, or via the worldwide guideline initiative, with expertise in the diagnosis of yeast, mold infections, and endemic mycoses. ECMM is the umbrella organization of 28 national mycological societies, comprised of one delegate from each of the 28 nations forming the ECMM council (www.ecmm.info) [10,11].

According to their expertise authors were divided into three groups and assigned to breakthrough IFI caused by yeasts $(n=3)$, molds $(n=3)$, and endemic mycoses $(n=2)$. The authors searched PubMed for relevant English language articles on clinical studies of antifungal prophylaxis and treatment through July 2020. Search terms included "diagnosis", "antifungal prophylaxis", "antifungal treatment", and "breakthrough fungal infection". Study selection and data extraction were performed separately for yeast infections, mold infections, and endemic mycoses, there was no strict methodical process for the literature search, and the inclusion or exclusion of studies was at the discretion of the authors of these sections. There was no intent to grade the quality of the studies. Authors then drafted a consensus statement for diagnosis of breakthrough IFI. 
A draft proposal for definitions was developed and sent out by the president of the ECMM to all ECMM council-members for critical revision, comments and suggestions, which were implemented into the final draft.

\section{Consensus Recommendations}

\subsection{Diagnosis of Breakthrough Infections Caused by Yeasts}

\subsubsection{Conventional Diagnostics}

Clinical samples analyzed when an invasive yeast infection is suspected depends on the suspected location(s) of fungal infections and typically include blood, urine, cerebrospinal fluid, or tissue biopsies for deep or systemic infections. Skin scrapings, shaved nail or hair, vaginal secretions, and swabs allow the detection of superficial infections [12].

Fungal culture is one of the primary lab-tests used to diagnose bIFI as it allows the identification of the fungal pathogen and supports antifungal susceptibility testing. Species identification and antifungal susceptibility profiles can help guide antifungal treatment. The most commonly used culture media are Sabouraud dextrose and malt extract agar plates. Additional specialized media such as chromogenic agar allow the separation of similar-looking colonies in cultures with mixed growth of more than one yeast genus or species and the direct identification of some Candida species $[13,14]$. The missed diagnosis of a mixed yeast infection is of particular significance for breakthrough fungal infections especially if the missed yeast genus/species is resistant to the antifungal drug in use. Utility of chromogenic agar as primary isolation medium may be of particular help in this respect. Matrix-assisted laser desorption ionization-time of flight mass spectrometry has become a standard tool for the accurate, rapid, and economical identification of pathogens in the clinical diagnostics laboratory [15].

Microscopic examination of a primarily sterile site can determine whether or not the infection is due to a fungus and differentiate between fungal colonization and IFI [14,16]. Microscopy, however, cannot determine the specific cause of infection. While Gram stain lacks optimal sensitivity, fluorescent brighteners (Calcofluor white, or Blankophor), which bind to chitin in the fungal cell wall, are a rapid means of scanning samples for fungal structures, and enhance morphology assessment [17].

Interpretation depends on the type of sample investigated [14,16]. Yeasts obtained from non-sterile body sites, like the oropharynx or airways, may be part of the mycobiota or may be the causative agent of the infection. Hence, global assessment of the patient, which includes consideration of the history and physical examination as well as the microbiological findings, is of utmost importance to determine if the recovered yeast represents colonization or is causing IFI. Appearances may be highly characteristic of certain infections, such as India ink in cerebrospinal fluid, which can identify encapsulated yeast genera such as Cryptococcus spp. The microscopic detection of typical budding yeast cells, pseudohyphae, and/or true hyphae in samples obtained from otherwise sterile sites is indicative of fungal infections.

\subsubsection{Serology Including Antigen-Based Tests}

Non-culture-based methods are increasingly used in clinical practice for the management of patients at high risk of fungal infection and can help reduce the time to diagnosis and allow for timely initiation of antifungal treatment. Antibody-based techniques are based on detecting circulating antigens in different body fluids. Enzyme-linked immunosorbent assay (ELISA) kits for detection of Candida mannan antigen are commercially available to detect Candida in serum samples for the diagnosis of invasive candidiasis (Platelia Candida Antigen, Bio-Rad Laboratories, Marnes-la-Coquette, France). When used in combination with anti-Candida mannan antibodies (Platelia Candida Antibody, Bio-Rad), this combination of serology tests has demonstrated good sensitivity (83\%) and specificity $(86 \%)$ [18]. However, the sensitivity of both mannan and anti-mannan vary for different Candida 
species, with lower sensitivity for C. parapsilosis and C. krusei [18]. Of note, the number of studies evaluating these assays is limited, and whether performance of mannan/anti-mannan is impacted by antifungal agents remains unknown.

The presence of $1,3-\beta-\mathrm{d}$-glucan (BDG) in serum can be used to diagnose some fungal infections (including Candida but not Cryptococcus). Since it is present in the cell wall of several fungal species [19], a positive result is not specific for invasive candidiasis. While the vast majority of studies to date evaluated the Fungitell ${ }^{\circledR}$ assay (Associates of Cape Cod Diagnostics, MA, USA), other commercial test are available which may show similar performance; however, optimal universal cut off values for non-Fungitell tests are still lacking [20,21]. Sensitivity and specificity for diagnosing invasive candidiasis are both around $80 \%$ [22,23], but false positive results have been described [24], in particular in conditions associated with fungal translocation in the gut such as sepsis or advanced liver cirrhosis $[25,26]$. BDG results should, therefore, be carefully evaluated and always interpreted with other clinical data. Serum BDG may be a useful tool for diagnosing bIFI; however, similar to other diagnostic tests, reduced sensitivities have been observed in the presence of antifungal prophylaxis or treatment $[27,28]$.

Cryptococcus antigen can be detected by a lateral flow assay (LFA; CrAg Immuno-Mycologics [IMMY], Norman, OK, USA), or via latex-agglutination (CryptoPlus assay, Bio-Rad). The LFA has high sensitivity $(98-100 \%)$ and specificity $(97-100 \%)$ in serum, plasma, cerebrospinal fluid, and urine and is the recommended biomarker for the diagnosis of cryptococcosis [29]. This assay has been extensively evaluated and it has been included in the "essential in vitro diagnostic list" of the WHO [30] and, thus, is recommended by the WHO for the screening and diagnosis of patients at risk for cryptococcal infection [31]. An ELISA kit is also available but is less commonly used due to a comparative performance with the LFA and the advantage of the LFA being a true point-of-care test (POCT).

\subsubsection{Nucleic Acid-Based Assays/Others}

Using molecular tools, it is possible to diagnose and identify yeasts directly from clinical samples (including blood, serum, plasma, other sterile fluid, bronchoalveolar lavage, and tissues) and to rapidly identify the species attributed for positive blood cultures during bloodstream infections.

A large number of commercial and in-house targeted (simplex or multiplex) PCR assays with specific primers for various genetic sequences (18S rDNA, 28S rDNA, 5.8S rDNA, internal transcribed spacer regions and mitochondrial DNA) have been developed [32,33], including for infections from C. auris and its relatives, C. haemulonii, C. duobushaemulonii, and C. pseudohaemulonii [34].

Depending on the assay, multiplex panels or pan-fungal panels are available. In a meta-analysis of 54 studies with almost 5000 patients tested by blood-based PCR, pooled sensitivity and specificity for proven or probable invasive candidiasis vs. at-risk controls were $95 \%$ and $92 \%$, respectively [35]. PCR plus blood culture, Candida PCR and, to a lesser extent, BDG testing, significantly enhanced the performance of PCR alone for the diagnosis of invasive candidiasis [28]. A recent and fully-automated assay combining internal transcribed spacer (ITS)2 region amplification and T2 magnetic resonance, the T2Candida ${ }^{\circledR}$ Panel (T2Biosystems, Wilmington, MA, USA), has been developed. This assay detects three groups of Candida (C. albicans/C. tropicalis, C. glabrata/C. krusei/C. bracarensis, and C. parapsilosis/C. orthopsilosis/C. metapsilosis) in EDTA blood samples within $5 \mathrm{~h}$ and proved efficient for the diagnosis of candidemia and of intra-abdominal candidiasis [36-38].

While blood cultures lack sensitivity, they still represent the diagnostic gold standard for candidemia and molecular blood culture identification (BCID) panels provide precise and rapid identification of cultured pathogens. Results are obtained with minimal hands-on time compared to conventional methods like chromogenic media and biochemical identification, proteomic identification using MALDI-TOF MS or fluorescence in situ hybridization (FISH) assays. Two BCID kits offer different fungal panels: The GenMark Dx ePlex (Carlsbad, CA, USA) fungal pathogen panel (BCID-FP) rapidly detects 15 fungal targets (C. albicans, C. auris, C. dubliniensis, C. famata, C. glabrata, C. guilliermondii, C. kefyr, C. krusei, C. lusitaniae, C. parapsilosis, C. tropicalis, Cryptococcus neoformans/gattii, Fusarium spp., and Rhodotorula spp.) [39] and the Biofire FilmArray BCID-FP (BioMérieux, 
Marcy-l'Etoile, France) (C. albicans, C. auris, C. glabrata, C. krusei, C. parapsilosis, C. tropicalis and Cryptococcus neoformans/gattii) [40].

Metagenomic next-generation sequencing (mNGS), which analyzes the nucleic acids from a broad spectrum of mixed populations of microorganisms simultaneously, is a strategy that can potentially identify the causative pathogen when other strategies have failed, and has been used to diagnose cryptococcal meningitis in multiple studies [41,42] and case reports [43]. Still, more rigorous studies of this strategy in breakthrough yeast infections before the use of this technology becomes widespread.

\subsubsection{Consensus Recommendation}

The cornerstone for diagnosing a breakthrough yeast infection relies on obtaining the isolate, most commonly with conventional culture methods. Prior antifungal treatment may confer a selection pressure for drug-resistant isolates. If a bIFI is diagnosed, the objective is to adapt the antifungal therapy to the species identified and to the in vitro susceptibility profile. The main steps of the diagnosis include the following:

- Direct examination of sterile samples is recommended for the proof of infection given the potential effect of antifungal therapy on fungal culture sensitivity. However, given limited sensitivity, a negative direct examination does not exclude infection.

- Once an isolate is grown, identification should be performed. Particularly in the case of a positive blood culture, molecular blood culture identification (BCID) panels provide precise and rapid identification.

- Antifungal susceptibility testing should be performed on invasive isolates to evaluate the activity of the current and alternative drugs.

- Non-culture methods of detection (serology and/or PCR) can be considered but the impact of antifungal therapy on their sensitivity has not been well-enough studied. Specificity is also a concern, especially with non-sterile samples, because highly sensitive molecular techniques can also reflect the presence of commensal yeasts.

\subsection{Diagnosis of Breakthrough Infections Caused by Molds}

\subsubsection{Conventional Diagnostics}

To establish a diagnosis of "proven" invasive mold infection per consensus definitions by the European Organization for Research and Treatment of Cancer (EORTC) and the MSGERC [44] or the AspICU algorithm by Blot and colleagues [45], or other definitions for the ICU setting [46], histopathologic, cytopathologic, or direct microscopic examination of a specimen obtained by needle aspiration or biopsy must show hyphae with evidence of associated tissue damage, recovery of mold by culture from a normally sterile site, or a positive blood culture with compatible signs and symptoms of infection. Although microscopy (optimally using optical brighteners) and culture are the traditional cornerstones for the diagnosis of invasive mold infection, most diagnoses are not made from a sterile site and the diagnosis is determined to be "probable" or "possible" per EORTC/MSGERC criteria, or putative according to AspICU criteria. In the case of clinical suspicion of a bIFI more aggressive invasive diagnostic procedures, including biopsies, may be warranted, if possible.

Culture-based approaches have the potential to detect the causative fungal pathogen and antifungal resistance and are the gold standard for investigating bIFI by Mucorales, Fusarium spp., Lomentospora spp., and other rare molds for which reliable antigens and other diagnosis are not available [47-50]. However, it is not always possible to attempt to obtain tissue biopsy for culture from a sterile site due to the risk of excessive bleeding or clinical contraindications, especially in patients with thrombocytopenia. In addition, culture-based approaches lack sensitivity. Positive blood culture is seen in fusariosis, lomentosporosis, and IA caused by Aspergillus terreus [49,51], but very rare in other cases of invasive aspergillosis (IA) [52]. Most cases of IA in immunocompromised patients are not proven by EORTC/MSGERC criteria (i.e., culture from a sterile site or biopsy evidence of invasion): for example, 
in one large survey of HSCT recipients, only $11.5 \%$ of patients with IA met the criteria for proven infection [53]. The sensitivity of culture is imperfect, ranging from $30-60 \%$ from bronchoalveolar lavage fluid (BALF) [54], and is lower for diagnosing bIFI in patients taking antifungals. In a study of 53 patients with diagnosed IFI, of which $34 / 53$ (64\%) were on mold-active antifungal prophylaxis, $16 / 53(30 \%)$ were diagnosed with "proven" infection, with a sensitivity of culture from BALF of only $3 / 16(18.8 \%)$ [8]. Similar low sensitivities of culture have been described in other studies for patients on mold-active antifungals [8,55-57]. Thus, the diagnosis of bIFI in many cases may be missed if diagnosis is relied on conventional diagnostics such as culture-based methods or microscopy alone. In addition to limited sensitivity, culture-based diagnostics involving non-sterile samples suffer from limited specificity: Positive culture results can represent fungal colonization which can lead to misdiagnosis and overtreatment [58]. Nevertheless, fungal culture and microscopy (from sterile sample) are essential for detecting rare mold infections, such as mucormycosis, fusariosis, scedosporiosis, lomentosporosis, and infections caused by other rare molds, such as Microascus (formerly Scopulariopsis), Rasamsonia, or basidiomycetes. These pathogens are normally only detected by fungal culture (or microscopy) with subsequent ITS sequencing or MALDI-TOF MS [59] of the isolate for species identification.

\subsubsection{Antigen-Based Diagnostics}

Although galactomannan (GM) detection plays a crucial role for the diagnosis of IA, several studies have shown that systematically screening for GM in blood for the detection of bIFI in patients receiving either posaconazole or micafungin during high-risk episodes is not useful due to the low prevalence of infection and the associated low positive predictive value of a positive test result $[60,61]$. As a consequence, the 2017 ESCMID-ECMM-European Respiratory Society (ERS) guidelines for the diagnosis and management of Aspergillus disease provides a recommendation against the use of serum GM screening in patients on mold-active prophylaxis [62]. However, antigen-based diagnostics remain critical to manage suspected fungal disease in these patients. Several studies demonstrated a better performance of GM detection in BAL versus blood, whereas BDG testing only provides reliable results in blood [63]. BAL GM testing may be particularly warranted in non-neutropenic patients, which often show an airway invasive growth pattern of IA, and therefore rarely produce positive serum GM results $[64,65]$. In a homogenous cohort of acute myeloid leukemia patients during induction chemotherapy, increasing the posaconazole concentration was shown to decrease the sensitivity of serum GM assay. In general, the sensitivity of serum GM assay to detect probable and proven IA is $81.8 \%$, but none of patients with IA and a posaconazole concentration $\geq 0.5 \mathrm{mg} / \mathrm{L}$ had a positive serum GM test [66]. Slightly reduced sensitivities in the presence of mold-active antifungals has also been described for the BAL GM: at a cut-off of 0.5 optical density index (ODI), Eigl and colleagues showed a $71 \%$ sensitivity for probable/proven IA in those on antifungals versus $95 \%$ in those without antifungals $[7,67,68]$. Sensitivity for diagnosing breakthrough IA in patients on antifungal prophylaxis dropped to $52 \%$ in that study when using a 1.0 ODI cutoff [68]. Therefore, using a lower cut-off of 0.5 ODI from BALF for diagnosing breakthrough IA may be preferable and was also recommended in another study [67]. Combining several antigen detection assays or antigen detection tests with PCR has shown convincing diagnostic potential for the diagnosis of breakthrough mold infections $[56,69,70]$. Data on the performance of the new lateral flow tests for the diagnosis of breakthrough IA, such as the AspLFD (OLM Diagnostics, Newcastle upon Tyne, UK; herein LFD) and the sōna Aspergillus galactomannan LFA (IMMY, Norman, OK, USA; herein LFA), are limited. For the LFD prototype test, sensitivity in BALF was only $52 \%$ in those receiving mold-active antifungals versus $86 \%$ in those not receiving mold-active antifungals [68], with a similar impact shown for serum LFD results in an animal model [27]. For the LFA, so far limited data has shown no significant impact of mold-active antifungals on efficacy [57,71-74]. Thus, both the LFA and the LFD are attractive options for the diagnosis of breakthrough infections in BALF and serum, especially when used in combination with other biomarkers [75]. Mold-active prophylaxis is affecting the epidemiology of invasive mycoses resulting in a shift towards less common entities such as fusariosis. In a retrospective cohort (2004-2017) 
from a tertiary hospital in Madrid, Spain, all $(n=7)$ cases of breakthrough invasive fusariosis were characterized by positive BDG tests in blood [76], and GM testing has also been shown to be useful for diagnosing fusariosis [77]. Lastly, a combination of multiple antigen-based diagnostics, conventional diagnostics, PCR-based assays, and novel diagnostic markers can help to diagnose breakthrough mold infections. Particularly, combination of GM with one or more other tests, such as the LFA, LFD, or PCR-based assays, shows promise for diagnosis of breakthrough IA in case of clinical suspicion, with positivity of one of those tests indicating breakthrough IA, even when others result negative.

\subsubsection{Nucleic Acid-Based Assays/Others}

Aspergillus PCR has demonstrated high sensitivity and high negative predictive value in severely immunocompromised patients in settings where antifungal prophylaxis is not used [78-81]. PCR is also an important diagnostic test for mucormycosis [82,83]. However, the performance of PCR from blood is impacted significantly in patients receiving mold-active antifungal agents as shown in a recent review $[8,55,81,84]$. While mold-active prophylaxis seems to affect Aspergillus PCR on BALF less than blood, reduced diagnostic performance has also been described from BALF [85]. Given the reduced sensitivity of all diagnostic tests in the presence of mold-active antifungal prophylaxis or treatment, the combination of multiple diagnostic tests is warranted $[8,55,56,69,86]$. Immunological markers may also be utilized as combination partners, and particularly high serum IL- 8 levels ( $>300 \mathrm{pg} / \mathrm{mL}$ ) have been shown to be highly specific for IA [56,87-89], and have shown high sensitivity and specificity when combined with BALF LFD or BALF Aspergillus PCR [56]. Larger multicenter studies are currently in progress to validate these findings. The most secreted siderophore of $A$. fumigatus is triacetylfusarinine $\mathrm{C}$ (TAFC), which is produced only by actively growing cells, is not present in conidia, and can be detected in urine, BALF and blood [90-92]. TAFC can be detected by mass spectrometry and has shown excellent performance as a biomarker for breakthrough IA in urine samples, when normalized to urine creatinine, with similar performance to those reported for GM determination in serum and BALF [90]. In BALF, TAFC was shown to be an independent biomarker for IA, improving the performance of BALF GM for detection of IA when used in combination [91]. These results warrant further exploration of this promising new biomarker. Other potential approaches for mycological detection of IA include the detection of volatile organic compounds in exhaled air [93], and Bis (methylthio) gliotoxin, an inactive derivative of gliotoxin [94].

\subsubsection{Consensus Recommendation}

The diagnosis of breakthrough mold infections is challenging, as all diagnostic tests have reduced sensitivity in samples obtained during treatment or prophylaxis with mold-active antifungals.

- Culture, microscopy, and antifungal susceptibility testing are essential for the diagnosis of breakthrough mold infections, particularly for infections other than invasive aspergillosis. Cultures of the lower respiratory tract are mostly preferred, although blood cultures may be positive in some cases. If necessary, and susceptibility testing, particularly for mold infections other than IA. Blood invasive procedures to obtain a biopsy and definite proof of bIFI should be considered. Importantly, a negative fungal culture does not rule out a breakthrough invasive mold infection, given the low sensitivity of culture in this setting.

- Despite reduced sensitivities, antigen-based diagnostics, such as GM (in BALF and serum) and BDG (in serum only), or newer assays, such as LFA and LFD (both in BALF or serum), have important roles for diagnosing breakthrough IA when the degree of clinical suspicion is high, because the sensitivity of fungal culture may be even further reduced.

- While we do not recommend using these tests for screening in patients on mold-active prophylaxis or treatment, a combination of multiple antigen-based diagnostics, conventional diagnostics, PCR-based assays, and novel diagnostic markers can help to diagnose breakthrough mold infections. 
- Many of the available antigen-based diagnostics such as GM or the LFA and the LFD tests are specific for IA and very few other mold infections such as fusariosis, therefore, negative test results do not automatically rule out a breakthrough mold infection, but instead should raise the suspicion for mucormycosis or another rare mold as a potential causative pathogen.

\subsection{Diagnosis of Breakthrough Infections Due to Endemic Mycoses}

\subsubsection{Conventional Diagnostics}

Diagnosis of the endemic mycoses (Blastomyces, Coccidioides, Emergomyces, Histoplasma, Paracoccidioides, Sporothrix spp., and Talaromyces marneffei (formerly Penicillium marneffei) is confirmed by histopathologic or direct microscopy of specimens from an affected site. Samples obtained by bronchoscopy are most frequently examined following pneumonia or when suspicious lesions are identified on radiographic imaging. However, biopsy results of affected sites or cerebrospinal fluid are also frequently helpful if cultures or typical in vivo findings of these fungi are observed [44].

Culture provides confirmation of infection and allows for susceptibility testing or identification to the species level, although the clinical correlation of susceptibility results to clinical outcomes has not been definitively demonstrated for the endemic mycoses. However, in vitro MICs do suggest resistance likely occurs [95,96], may develop on therapy [97], and may be increasing in frequency [98,99]. With attempts at culture isolation, biosafety is an important consideration when handling these organisms, and laboratories should incorporate national guidance and regulations into their processes and practices to ensure the safety of laboratory staff.

\subsubsection{Serology}

Serologic testing is widely used for the diagnosis and care of patients with coccidioidomycosis. In this group, serology has been found to be helpful diagnostically, but also correlates with patient symptoms and is useful to follow prognostically as a biomarker of infection. For example, relapse of infection in patients with coccidioidomycosis is typically accompanied by a rise in the complement fixation (CF) antibody titer [100]. Serology of blastomycosis is less helpful due to the lower sensitivity and specificity of testing [101-103]. Serologic testing for histoplasmosis utilizing antigen testing is most useful for patients with chronic pulmonary disease and may not be helpful in those with severe immunosuppression [104-107]. Still, in the right patient quantitative antigen methods with monitoring of Histoplasma antigen titers can allow for monitoring response during treatment [54]. In contrast, paracoccidioidomycosis serologies exhibit high sensitivity and specificity [108-110]. Sporotrichosis serologic testing is infrequently used due to the lack of a commercial assay, while the sensitivity of antibody testing for talaromycosis ranges from $30-80 \%$ likely due to the highly immunosuppressed state (e.g., advanced HIV disease) of most affected patients [111,112].

It is important to recall that in the immunosuppressed patient population the endemic mycoses, particularly Coccidioides or Histoplasma, may recur years after initial infection, and serology may not be positive or may have aberrant kinetics compared to immunocompetent hosts [100,113,114].

Prior to initiating immunosuppressive therapy, it is often prudent to evaluate a patient's past travel history to determine the individual risk for endemic mycoses. For those with a suggestive history, serologic testing can be performed to ascertain the potential need or to guide prophylaxis/treatment practices to avoid potential breakthrough infection later.

Antigen testing for Blastomyces spp. is commercially available and has a reported sensitivity of $85-93 \%$ and a specificity of 79-99\% [115-119]. Test positivity in Coccidioides depends upon the degree of host immunosuppression and is largely unhelpful in the immunocompetent. In highly immunosuppressed patients, antigenuria has been detected in up to $70 \%$ of patients [120]. Histoplasma antigen assays are most useful in patients who have disseminated histoplasmosis and acute pulmonary histoplasmosis, but are less useful in localized pulmonary infection and chronic cavitary pulmonary histoplasmosis [121,122]. Antigen detection for paracoccidioidomycosis has been 
investigated although is not commercially available [123], and has not been evaluated for sporotrichosis. Antigen detection in talaromycosis is highly accurate and is well suited for patients with advanced immunosuppression and a high blood fungal burden [124]. However, it is not widely available.

\subsubsection{Nucleic Acid Based Assays/Others}

Nucleic acid amplification using polymerase chain reaction (PCR) tests are not commercially available for the endemic mycoses, but detection of DNA in clinical specimens has been evaluated for: Blastomyces (sensitivity 60-86\%) [125-127], Coccidioides ( 50\%) [128,129], Histoplasma (18-65\%) [106,130], Paracoccidioides (91-100\%) [114,131] Sporothrix (83-92\%) [132-134], and Talaromyces (70-86\%) [135].

The use of BDG for the diagnosis of endemic mycosis is problematic due to the lack of specificity and the poor positive predictive value and although have been evaluated in limited fashion, are generally unhelpful in the diagnosis or management of endemic mycoses [136,137].

\subsubsection{Consensus Recommendation}

Specific recommendations for diagnosis of breakthrough endemic mycoses include:

- Whenever possible, diagnosis of bIFI caused by endemic mycoses should be confirmed by obtaining affected tissue for examination by direct microscopy, histopathology, and fungal culture.

- More nuanced approaches are required for individual diseases that are suspected based on the relevant clinical picture and exposure history. In acute disease in immunocompromised patients, histoplasmosis and talaromycosis can both be diagnosed with antigen tests, although the latter assay is not widely available.

- Antibody tests for coccidioidomycosis, paracoccidioidomycosis, and acute and chronic histoplasmosis should be considered, but antibody tests for histoplasmosis are not recommended in patients with immunosuppression or those with cystic fibrosis. Serology for other endemic mycoses (i.e., blastomycosis, sporotrichosis, emergomycosis) have limited sensitivities and specificities or are not commercially available.

\section{Discussion}

The diagnosis of bIFIs remain challenging, with limited sensitivities of most available fungal diagnostics. With these consensus recommendations we intend to support the design of future clinical trials in the field of clinical mycology.

The diagnosis of breakthrough yeast infections and the endemic mycoses should rely on the isolation of the causative pathogen, such as by conventional culture methods, although the yield is often reduced in patients on antifungal prophylaxis, making diagnosis of bIFI even more challenging. In addition, while culture-based methods can enable species identification and antifungal susceptibility profiles to help guide antifungal treatment breakpoints, such as the minimum inhibitory concentration (MIC) that measure in vitro drug activity, do not always reliably predict in vivo drug activity and clinical outcome. For instance, the pharmacokinetic/pharmacodynamic properties of the drug, potential drug-drug interactions, and the overall health and immune status of the patient receiving the antifungal drug can all affect the in vivo activity of the drug in the human body [13]. Other non-culture methods such as BDG and PCR for the diagnosis of yeast infection and serologic tests for acute histoplasmosis and coccidioidomycosis can be considered, but the effect of antifungal therapy likely decreases the yield of these tests, although this has not been well-studied.

Conversely, antigen-based assays, such as GM, the LFD, and LFA, have an important role in the diagnosis of breakthrough invasive mold infections, although antifungal therapy may reduce the sensitivity of these assays and a combination of multiple antigen-based diagnostics, along with conventional culture and PCR-based assays, may further increase the diagnostic yield. Breakthrough infections occurring under antifungal prophylaxis mostly require combinations of multiple tests and biomarkers in order to achieve an acceptable sensitivity. Optimally, diagnostic approaches for fungal 
infections should be initiated before initiation of antifungal treatment, however in the real world this is often not possible.

More effective, simpler, and cheaper diagnostic tests are needed with more rapid turnaround time to diagnose bIFIs, particularly non-Aspergillus mold infections and endemic mycosis. Given that antifungal therapy can decrease the diagnostic yield of conventional culture and several serologic and PCR-based assays discussed, improved diagnostics, particularly for bIFIs, are needed. While these definitions represent the status of published literature, future studies are needed to fill important gaps.

Author Contributions: J.D.J. and M.H. coordinated the consensus recommendations. J.D.J., J.-P.G., I.S.S., A.A.-I., K.L., G.R.T.III, C.L.-F., and M.H. all contributed equally to the literature search, writing of the first draft, critical revision, and finalization of this manuscript. The ECMM Council investigators performed additional literature search and critically reviewed and revised the draft proposal. All authors have read and agreed to the published version of the manuscript.

Funding: This research received no external funding.

Conflicts of Interest: M.H. received grant funding from Gilead and Pfizer. J.P.G. received grant funding from Pfizer. C.L.F. received grants from Gilead, Pfizer, and Basilea, however, these funders have no influence on this manuscript. ISS has received an honorarium for serving on an advisory board from AVIR Inc. outside of the submitted work. G.R.T. received consulting and research support from Amplyx, Astellas, Cidara, F2G, Mayne, Scynexis, and research support from Gilead, Merck, Regeneron, and Pfizer outside the submitted work. A.A.-I. has received research grants or honoraria as a speaker from Astellas, Gilead Sciences, MSD, Pfizer, F2G, Amplyx, and Scynexis outside the submitted work. K.L. received MSD, SMB Laboratoires Brussels, and Gilead; travel support from Pfizer and MSD; speaker fees from Gilead, FUJIFILM WAKO, and Pfizer; and a grant from Thermo Fisher Scientific, outside the submitted work. SAA reports speaker honoraria or travel grant from Astellas, Gilead, and Pfizer outside the submitted work. ER has received research grants from Astellas, Gilead, Merck, and Pfizer Inc.; he is a scientific advisor and member of speaker bureaus for Astellas, Gilead, Merck, and Pfizer Inc. OAC is supported by the German Federal Ministry of Research and Education, is funded by the Deutsche Forschungsgemeinschaft (DFG, German Research Foundation) under Germany's Excellence Strategy-CECAD, EXC 2030-390661388 and has received research grants from Actelion, Amplyx, Astellas, Basilea, Cidara, Da Volterra, F2G, Gilead, Janssen, Medicines Company, Melinta, Merck/MSD, Octapharma, Pfizer, Scynexis, is a consultant to Actelion, Allecra, Amplyx, Astellas, Basilea, Biosys, Cidara, Da Volterra, Entasis, F2G, Gilead, Matinas, MedPace, Menarini, Merck/MSD, Mylan, Nabriva, Noxxon, Octapharma, Paratek, Pfizer, PSI, Roche Diagnostics, Scynexis, and Shionogi, and received lecture honoraria from Al-Jazeera Pharmaceuticals, Astellas, Basilea, Gilead, Grupo Biotoscana, Merck/MSD, and Pfizer. ER has received research grants from Astellas, Gilead, Merck, and Pfizer Inc.; he is a scientific advisor and member of speaker bureaus for Astellas, Gilead, Merck, and Pfizer Inc. All other authors have no potential conflicts of interest to disclose. The funders had no role in the design of the study; in the collection, analyses, or interpretation of data; in the writing of the manuscript; or in the decision to publish the results.

\section{References}

1. Jenks, J.D.; Cornely, O.A.; Chen, S.C.; Thompson, G.R., III; Hoenigl, M. Breakthrough Invasive Fungal Infections: Who is at risk? Mycoses 2020, 63, 1021-1032. [CrossRef] [PubMed]

2. Lee, W.-S.; Hsieh, T.-C.; Ou, T.-Y.; Teng, S.-O.; Chen, F.-L.; Lee, W.-S. Breakthrough disseminated cryptococcosis during micafungin therapy. J. Microbiol. Immunol. Infect. 2015, 48, 456-458. [CrossRef] [PubMed]

3. Cornely, O.A.; Hoenigl, M.; Lass-Flörl, C.; Chen, S.C.-A.; Kontoyiannis, D.P.; Morrissey, C.O.; Iii, G.R.T.; for the Mycoses Study Group Education and Research Consortium (MSG-ERC) and the European Confederation of Medical Mycology (ECMM); Lass-Flör, C.; Mycoses Study Group Education and Research Consortium (MSG-ERC) and the European Confederation of Medical Mycology (ECMM); et al. Defining breakthrough invasive fungal infection-Position paper of the mycoses study group education and research consortium and the European Confederation of Medical Mycology. Mycoses 2019, 62, 716-729. [CrossRef] [PubMed]

4. Jenks, J.; Spiess, B.; Buchheidt, D.; Hoenigl, M. (New) Methods for Detection of Aspergillus fumigatus Resistance in Clinical Samples. Curr. Fungal Infect. Rep. 2019, 13, 129-136. [CrossRef]

5. Buchheidt, D.; Reinwald, M.; Hoenigl, M.; Hofmann, W.-K.; Spiess, B.; Boch, T. The evolving landscape of new diagnostic tests for invasive aspergillosis in hematology patients. Curr. Opin. Infect. Dis. 2017, 30, 539-544. [CrossRef]

6. Hoenigl, M.; Prattes, J.; Neumeister, P.; Wölfler, A.; Krause, R. Real-world challenges and unmet needs in the diagnosis and treatment of suspected invasive pulmonary aspergillosis in patients with haematological diseases: An illustrative case study. Mycoses 2017, 61, 201-205. [CrossRef] 
7. Eigl, S.; Prattes, J.; Reinwald, M.; Thornton, C.R.; Reischies, F.; Spiess, B.; Neumeister, P.; Zollner-Schwetz, I.; Raggam, R.B.; Flick, H.; et al. Influence of mould-active antifungal treatment on the performance of the Aspergillus-specific bronchoalveolar lavage fluid lateral-flow device test. Int. J. Antimicrob. Agents 2015, 46, 401-405. [CrossRef]

8. $\quad$ Eigl, S.; Hoenigl, M.; Spiess, B.; Heldt, S.; Prattes, J.; Neumeister, P.; Wölfler, A.; Rabensteiner, J.; Prueller, F.; Krause, R.; et al. Galactomannan testing and Aspergillus PCR in same-day bronchoalveolar lavage and blood samples for diagnosis of invasive aspergillosis. Med. Mycol. 2017, 55, 528-534.

9. Hoenigl, M.; Seeber, K.; Koidl, C.; Buzina, W.; Wölfler, A.; Duettmann, W.; Wagner, J.; Strenger, V.; Krause, R. Sensitivity of galactomannan enzyme immunoassay for diagnosing breakthrough invasive aspergillosis under antifungal prophylaxis and empirical therapy. Mycoses 2013, 56, 471-476. [CrossRef]

10. Cornely, O.A.; Lass-Flörl, C.; Lagrou, K.; Arsic-Arsenijevic, V.; Hoenigl, M. Improving outcome of fungal diseases - Guiding experts and patients towards excellence. Mycoses 2017, 60, 420-425. [CrossRef]

11. Hoenigl, M.; Gangneux, J.-P.; Segal, E.; Alanio, A.; Chakrabarti, A.; Chen, S.C.-A.; Govender, N.P.; Hagen, F.; Klimko, N.; Meis, J.F.; et al. Global guidelines and initiatives from the European Confederation of Medical Mycology to improve patient care and research worldwide: New leadership is about working together. Mycoses 2018, 61, 885-894. [CrossRef] [PubMed]

12. Wickes, B.L.; Romanelli, A.M. Diagnostic Mycology: Xtreme Challenges. J. Clin. Microbiol. $2020,58$. [CrossRef] [PubMed]

13. Berkow, E.L.; Lockhart, S.R.; Ostrosky-Zeichner, L. Antifungal Susceptibility Testing: Current Approaches. Clin. Microbiol. Rev. 2020, 33. [CrossRef] [PubMed]

14. Cuenca-Estrella, M.; Verweij, P.E.; Arendrup, M.C.; Arikan-Akdagli, S.; Bille, J.; Donnelly, J.P.; Jensen, H.E.; Lass-Flörl, C.; Richardson, M.D.; Akova, M.; et al. ESCMID* guideline for the diagnosis and management of Candida diseases 2012: Diagnostic procedures. Clin. Microbiol. Infect. 2012, 18, 9-18. [CrossRef] [PubMed]

15. Mery, A.; Sendid, B.; François, N.; Cornu, M.; Poissy, J.; Guerardel, Y.; Poulain, D. Application of Mass Spectrometry Technology to Early Diagnosis of Invasive Fungal Infections. J. Clin. Microbiol. 2016, 54, 2786-2797. [CrossRef] [PubMed]

16. Lass-Flörl, C. How to make a fast diagnosis in invasive aspergillosis. Med. Mycol. 2019, 57, S155-S160. [CrossRef] [PubMed]

17. Clancy, C.J.; Nguyen, M.-H. Rapid diagnosis of invasive candidiasis. Curr. Opin. Infect. Dis. 2019, 32, 546-552. [CrossRef]

18. Mikulska, M.; Calandra, T.; Sanguinetti, M.; Poulain, D.; Viscoli, C. The Third European Conference on Infections in Leukemia Group The use of mannan antigen and anti-mannan antibodies in the diagnosis of invasive candidiasis: Recommendations from the Third European Conference on Infections in Leukemia. Crit. Care 2010, 14, R222. [CrossRef]

19. Ostrosky-Zeichner, L.; Alexander, B.D.; Kett, D.H.; Vazquez, J.; Pappas, P.G.; Saeki, F.; Ketchum, P.A.; Wingard, J.; Schiff, R.; Tamura, H.; et al. Multicenter clinical evaluation of the (1->3) beta-D-glucan assay as an aid to diagnosis of fungal infections in humans. Clin. Infect. Dis. 2005, 41, 654-659. [CrossRef]

20. Marchetti, O.; Lamoth, F.; Mikulska, M.; Viscoli, C.; Verweij, P.; Bretagne, S. ECIL recommendations for the use of biological markers for the diagnosis of invasive fungal diseases in leukemic patients and hematopoietic SCT recipients. Bone Marrow Transplant. 2011, 47, 846-854. [CrossRef]

21. Friedrich, R.; Rappold, E.; Bogdan, C.; Held, J. Comparative Analysis of the Wako $\beta$-Glucan Test and the Fungitell Assay for Diagnosis of Candidemia and Pneumocystis jirovecii Pneumonia. J. Clin. Microbiol. 2018, 56, e00464-18. [CrossRef] [PubMed]

22. Onishi, A.; Sugiyama, D.; Kogata, Y.; Saegusa, J.; Sugimoto, T.; Kawano, S.; Morinobu, A.; Nishimura, K.; Kumagai, S. Diagnostic Accuracy of Serum 1,3- $\beta$-d-Glucan for Pneumocystis jiroveci Pneumonia, Invasive Candidiasis, and Invasive Aspergillosis: Systematic Review and Meta-Analysis. J. Clin. Microbiol. 2011, 50, 7-15. [CrossRef] [PubMed]

23. Karageorgopoulos, D.E.; Vouloumanou, E.K.; Ntziora, F.; Michalopoulos, A.; Rafailidis, P.I.; Falagas, M.E. beta-D-glucan assay for the diagnosis of invasive fungal infections: A meta-analysis. Clin. Infect. Dis. 2011, 52, 750-770. [CrossRef] [PubMed]

24. Liss, B.J.; Cornely, O.A.; Hoffmann, D.; Dimitriou, V.; Wisplinghoff, H. 1,3-ß-D-glucan concentrations in blood products predict false positive post-transfusion results. Mycoses 2015, 59, 39-42. [CrossRef] 
25. Hoenigl, M. Fungal Translocation: A driving force behind the Occurrence of non-AIDS Events? Clin. Infect. Dis. 2019, 70, 242-244. [CrossRef]

26. Yang, A.-M.; Inamine, T.; Hochrath, K.; Chen, P.; Wang, L.; Llorente, C.; Bluemel, S.; Hartmann, P.; Xu, J.; Koyama, Y.; et al. Intestinal fungi contribute to development of alcoholic liver disease. J. Clin. Investig. 2017, 127, 2829-2841. [CrossRef]

27. Wiederhold, N.P.; Najvar, L.K.; Bocanegra, R.; Kirkpatrick, W.R.; Patterson, T.F.; Thornton, C.R. Interlaboratory and Interstudy Reproducibility of a Novel Lateral-Flow Device and Influence of Antifungal Therapy on Detection of Invasive Pulmonary Aspergillosis. J. Clin. Microbiol. 2012, 51, 459-465. [CrossRef]

28. Nguyen, M.H.; Wissel, M.C.; Shields, R.K.; Salomoni, M.A.; Hao, B.; Press, E.G.; Shields, R.M.; Cheng, S.; Mitsani, D.; Vadnerkar, A.; et al. Performance of Candida real-time polymerase chain reaction, beta-D-glucan assay, and blood cultures in the diagnosis of invasive candidiasis. Clin. Infect. Dis. 2012, 54, 1240-1248. [CrossRef]

29. Vidal, J.E.; Boulware, D.R. Lateral flow assay for cryptococcal antigen: An important advance to improve the continuum of hiv care and reduce cryptococcal meningitis-related mortality. Rev. Inst. Med. Trop. São Paulo 2015, 57, 38-45. [CrossRef]

30. First WHO Model List of Essential In Vitro Diagnostics; World Health Organization: Geneva, Switzerland, 2019.

31. WHO Guidelines Approved by the Guidelines Review Committee. Guidelines for the Diagnosis, Prevention and Management of Cryptococcal Disease in HIV-Infected Adults, Adolescents and Children: Supplement to the 2016 Consolidated Guidelines on the Use of Antiretroviral Drugs for Treating and Preventing HIV Infection; World Health Organization: Geneva, Switzerland, 2018.

32. Camp, I.; Spettel, K.; Willinger, B. Molecular Methods for the Diagnosis of Invasive Candidiasis. J. Fungi 2020, 6, 101. [CrossRef]

33. Clancy, C.J.; Nguyen, M. Non-Culture Diagnostics for Invasive Candidiasis: Promise and Unintended Consequences. J. Fungi 2018, 4, 27. [CrossRef] [PubMed]

34. Arastehfar, A.; Fang, W.; Daneshnia, F.; Al-Hatmi, A.M.S.; Liao, W.; Pan, W.; Khan, Z.; Ahmad, S.; Rosam, K.; Lackner, M.; et al. Novel multiplex real-time quantitative PCR detecting system approach for direct detection of Candida auris and its relatives in spiked serum samples. Futur. Microbiol. 2019, 14, 33-45. [CrossRef] [PubMed]

35. Avni, T.; Leibovici, L.; Paul, M. PCR Diagnosis of Invasive Candidiasis: Systematic Review and Meta-Analysis. J. Clin. Microbiol. 2010, 49, 665-670. [CrossRef] [PubMed]

36. Zurl, C.J.; Prattes, J.; Zollner-Schwetz, I.; Valentin, T.; Rabensteiner, J.; Wunsch, S.; Hoenigl, M.; Krause, R. T2Candida magnetic resonance in patients with invasive candidiasis: Strengths and limitations. Med. Mycol. 2019, 58. [CrossRef] [PubMed]

37. Clancy, C.J.; Pappas, P.G.; Vazquez, J.; Judson, M.A.; Kontoyiannis, D.P.; Thompson, G.R.; Garey, K.W.; Reboli, A.; Greenberg, R.N.; Apewokin, S.; et al. Detecting Infections Rapidly and Easily for Candidemia Trial, Part 2 (DIRECT2): A Prospective, Multicenter Study of the T2Candida Panel. Clin. Infect. Dis. 2018, 66, 1678-1686. [CrossRef]

38. Elamoth, F.; Clancy, C.J.; Tissot, F.; Squires, K.; Eggimann, P.; Flückiger, U.; Siegemund, M.; Orasch, C.; Zimmerli, S.; Calandra, T.; et al. Performance of the T2Candida Panel for the Diagnosis of Intra-abdominal Candidiasis. Open Forum Infect. Dis. 2020, 7, ofaa075. [CrossRef]

39. Zhang, G.; Hu, C.; Luo, L.; Fang, F.; Chen, Y.; Li, J.; Peng, Z.; Pan, H. Clinical features and short-term outcomes of 221 patients with COVID-19 in Wuhan, China. J. Clin. Virol. 2020, 127, 104364. [CrossRef]

40. Simor, A.E.; Porter, V.; Mubareka, S.; Chouinard, M.; Katz, K.; Vermeiren, C.; Fattouh, R.; Matukas, L.M.; Tadros, M.; Mazzulli, T.; et al. Rapid Identification of Candida Species from Positive Blood Cultures by Use of the FilmArray Blood Culture Identification Panel. J. Clin. Microbiol. 2018, 56. [CrossRef]

41. Ramachandran, P.S.; Cresswell, F.V.; Meya, D.B.; Langelier, C.; Crawford, E.D.; DeRisi, J.L.; Boulware, D.R.; Wilson, M.R. Detection of Cryptococcus DNA by Metagenomic Next-generation Sequencing in Symptomatic Cryptococcal Antigenemia. Clin. Infect. Dis. 2018, 68, 1978-1979. [CrossRef]

42. Xing, X.-W.; Zhang, J.-T.; Ma, Y.-B.; Zheng, N.; Yang, F.; Yu, S.-Y. Apparent performance of metagenomic next-generation sequencing in the diagnosis of cryptococcal meningitis: A descriptive study. J. Med. Microbiol. 2019, 68, 1204-1210. [CrossRef] 
43. Zhang, C.; Wang, C.; Chen, F.; Huang, Z.; Fang, X.; Li, W.; Yang, B.; Zhang, W. Metagenomic Next-Generation Sequencing Technique Helps Identify Cryptococcal Infection in the Rib. JBJS Case Connect. 2019, 9, e0367. [CrossRef] [PubMed]

44. Donnelly, J.P.; Chen, S.C.; Kauffman, C.A.; Steinbach, W.J.; Baddley, J.W.; Verweij, P.E.; Clancy, C.J.; Wingard, J.R.; Lockhart, S.R.; Groll, A.H.; et al. Revision and Update of the Consensus Definitions of Invasive Fungal Disease from the European Organization for Research and Treatment of Cancer and the Mycoses Study Group Education and Research Consortium. Clin. Infect. Dis. 2019, 71, 1367-1376. [CrossRef] [PubMed]

45. Blot, S.I.; Taccone, F.S.; Abeele, A.-M.V.D.; Bulpa, P.; Meersseman, W.; Brusselaers, N.; Dimopoulos, G.; Paiva, J.A.; Misset, B.; Rello, J.; et al. A Clinical Algorithm to Diagnose Invasive Pulmonary Aspergillosis in Critically Ill Patients. Am. J. Respir. Crit. Care Med. 2012, 186, 56-64. [CrossRef] [PubMed]

46. Verweij, P.E.; Rijnders, B.; Bruggemann, R.J.; Azoulay, E.; Bassetti, M.; Blot, S.; Calandra, T.; Clancy, C.J.; Cornely, O.A.; Chiller, T.; et al. Review of influenza-associated pulmonary aspergillosis in ICU patients and proposal for a case definition: An expert opinion. Intensiv. Care Med. 2020, 46, 1524-1535. [CrossRef] [PubMed]

47. Cornely, O.A.; Alastruey-Izquierdo, A.; Arenz, D.; Chen, S.C.A.; Dannaoui, E.; Hochhegger, B.; Hoenigl, M.; Jensen, H.E.; Lagrou, K.; Lewis, R.E.; et al. Global guideline for the diagnosis and management of mucormycosis: An initiative of the European Confederation of Medical Mycology in cooperation with the Mycoses Study Group Education and Research Consortium. Lancet Infect. Dis. 2019, 19, e405-e421. [CrossRef]

48. Jenks, J.D.; Seidel, D.; Cornely, O.A.; Chen, S.; Van Hal, S.; Kauffman, C.; Miceli, M.H.; Heinemann, M.; Christner, M.; Sáenz, A.J.; et al. Voriconazole plus terbinafine combination antifungal therapy for invasive Lomentospora prolificans infections: Analysis of 41 patients from the FungiScopeßregistry 2008-2019. Clin. Microbiol. Infect. 2020, 26, 784.e1-784.e5. [CrossRef] [PubMed]

49. Jenks, J.D.; Seidel, D.; Cornely, O.A.; Chen, S.; Van Hal, S.; Kauffman, C.; Miceli, M.H.; Heinemann, M.; Christner, M.; Sáenz, A.J.; et al. Clinical Characteristics and Outcomes of invasive Lomentospora prolificans Infections: Analysis of Patients in the FungiScope®Registry. Mycoses 2020, 2020. [CrossRef] [PubMed]

50. Jenks, J.D.; Reed, S.L.; Seidel, D.; Koehler, P.; Cornely, O.A.; Mehta, S.R.; Hoenigl, M. Rare Mold Infections Caused by Mucorales, Lomentospora Prolificans and Fusarium, San Diego: The Role of Antifungal Combination Therapy. Int. J. Antimicrob. Agents 2018, 52, 706-712. [CrossRef]

51. Nucci, M.; Marr, K.; Vehreschild, M.; De Souza, C.; Velasco, E.; Cappellano, P.; Carlesse, F.; Queiroz-Telles, F.; Sheppard, D.; Kindo, A.; et al. Improvement in the outcome of invasive fusariosis in the last decade. Clin. Microbiol. Infect. 2014, 20, 580-585. [CrossRef]

52. Kontoyiannis, D.P.; Sumoza, D.; Tarrand, J.; Bodey, G.P.; Storey, R.; Raad, I. Significance of Aspergillemia in Patients with Cancer: A 10-Year Study. Clin. Infect. Dis. 2000, 31, 188-189. [CrossRef]

53. Neofytos, D.; Horn, D.; Anaissie, E.; Steinbach, W.; Olyaei, A.; Fishman, J.; Pfaller, M.; Chang, C.; Webster, K.; Marr, K. Epidemiology and Outcome of Invasive Fungal Infection in Adult Hematopoietic Stem Cell Transplant Recipients: Analysis of Multicenter Prospective Antifungal Therapy (PATH) Alliance Registry. Clin. Infect. Dis. 2009, 48, 265-273. [CrossRef] [PubMed]

54. Hage, C.A.; Carmona, E.M.; Evans, S.E.; Limper, A.H.; Ruminjo, J.; Thomson, C.C. Summary for Clinicians: Microbiological Laboratory Testing in the Diagnosis of Fungal Infections in Pulmonary and Critical Care Practice. Ann. Am. Thorac. Soc. 2019, 16, 1473-1477. [CrossRef] [PubMed]

55. Reischies, F.M.; Raggam, R.B.; Prattes, J.; Krause, R.; Eigl, S.; List, A.; Quehenberger, F.; Strenger, V.; Wölfler, A.; Hoenigl, M. Urine Galactomannan-to-Creatinine Ratio for Detection of Invasive Aspergillosis in Patients with Hematological Malignancies. J. Clin. Microbiol. 2016, 54, 771-774. [CrossRef] [PubMed]

56. Heldt, S.; Prattes, J.; Eigl, S.; Spiess, B.; Flick, H.; Rabensteiner, J.; Johnson, G.; Prüller, F.; Wölfler, A.; Niedrist, T.; et al. Diagnosis of invasive aspergillosis in hematological malignancy patients: Performance of cytokines, Asp LFD, and Aspergillus PCR in same day blood and bronchoalveolar lavage samples. J. Infect. 2018, 77, 235-241. [CrossRef] [PubMed]

57. Jenks, J.D.; Mehta, S.R.; Taplitz, R.; Law, N.; Reed, S.L.; Hoenigl, M. Bronchoalveolar lavage Aspergillus Galactomannan lateral flow assay versus Aspergillus-specific lateral flow device test for diagnosis of invasive pulmonary Aspergillosis in patients with hematological malignancies. J. Infect. 2019, 78, 249-259. [CrossRef] [PubMed] 
58. Paterson, D.L.; Singh, N. Invasive Aspergillosis in Transplant Recipients. Medicine 1999, 78, $123-133$. [CrossRef] [PubMed]

59. Walsh, T.J.; McCarthy, M.W. The expanding use of matrix-assisted laser desorption/ionization-time of flight mass spectroscopy in the diagnosis of patients with mycotic diseases. Expert Rev. Mol. Diagn. 2019, 19, 241-248. [CrossRef] [PubMed]

60. Duarte, R.F.; Sánchez-Ortega, I.; Cuesta, I.; Arnan, M.; Patiño, B.; De Sevilla, A.F.; Gudiol, C.; Ayats, J.; Cuenca-Estrella, M. Serum Galactomannan-Based Early Detection of Invasive Aspergillosis in Hematology Patients Receiving Effective Antimold Prophylaxis. Clin. Infect. Dis. 2014, 59, 1696-1702. [CrossRef] [PubMed]

61. Vena, A.; Bouza, E.; Álvarez-Uría, A.; Gayoso, J.; Martín-Rabadán, P.; Cajuste, F.; Guinea, J.; Castellá, J.G.; Alonso, R.; Muñoz, P. The misleading effect of serum galactomannan testing in high-risk haematology patients receiving prophylaxis with micafungin. Clin. Microbiol. Infect. 2017, 23, 1000.e1-1000.e4. [CrossRef]

62. Ullmann, A.J.; Aguado, J.M.; Arikan-Akdagli, S.; Denning, D.W.; Groll, A.H.; Lagrou, K.; Lass-Flörl, C.; Lewis, R.E.; Munoz, P.; Verweij, P.E.; et al. Executive Summary of the 2017 ESCMID-ECMM Guideline for the Diagnosis and Management of Aspergillus Disease. Clin. Microb. Infect. 2018, 24, e1-e38. [CrossRef]

63. Reischies, F.; Prattes, J.; Prüller, F.; Eigl, S.; List, A.; Wölfler, A.; Buzina, W.; Zollner-Schwetz, I.; Valentin, T.; Rabensteiner, J.; et al. Prognostic potential of 1,3-beta-d-glucan levels in bronchoalveolar lavage fluid samples. J. Infect. 2016, 72, 29-35. [CrossRef] [PubMed]

64. Danese, S.; Gangneux, J.-P.; Bassetti, M.; Brüggemann, R.J.M.; Cornely, O.A.; Koehler, P.; Lass-Flörl, C.; Van De Veerdonk, F.L.; Chakrabarti, A.; Hoenigl, M. Diagnosing COVID-19-associated pulmonary aspergillosis. Lancet Microbe 2020, 1, e53-e55. [CrossRef]

65. Bergeron, A.; Porcher, R.; Sulahian, A.; De Bazelaire, C.; Chagnon, K.; Raffoux, E.; Vekhoff, A.; Cornet, M.; Isnard, F.; Brethon, B.; et al. The strategy for the diagnosis of invasive pulmonary aspergillosis should depend on both the underlying condition and the leukocyte count of patients with hematologic malignancies. Blood 2012, 119, 1831-1837. [CrossRef] [PubMed]

66. Calmettes, C.; Gabriel, F.; Blanchard, E.; Servant, V.; Bouchet, S.; Kabore, N.; Forcade, E.; Leroyer, C.; Bidet, A.; Latrabe, V.; et al. Breakthrough invasive aspergillosis and diagnostic accuracy of serum galactomannan enzyme immune assay during acute myeloid leukemia induction chemotherapy with posaconazole prophylaxis. Oncotarget 2018, 9, 26724-26736. [CrossRef]

67. Reinwald, M.; Spiess, B.; Heinz, W.J.; Vehreschild, J.J.; Lass-Flörl, C.; Kiehl, M.; Schultheis, B.; Krause, S.W.; Wolf, H.-H.; Bertz, H.; et al. Diagnosing pulmonary aspergillosis in patients with hematological malignancies: A multicenter prospective evaluation of an Aspergillus PCR assay and a galactomannan ELISA in bronchoalveolar lavage samples. Eur. J. Haematol. 2012, 89, 120-127. [CrossRef]

68. Salzer, H.J.F.; Lange, C.; Hoenigl, M. Aspergillus in airway material: Ignore or treat? Internist (Berl.) 2017, 58, 1150-1162. [CrossRef]

69. Boch, T.; Spiess, B.; Cornely, O.A.; Vehreschild, J.J.; Rath, P.M.; Steinmann, J.; Heinz, W.J.; Hahn, J.; Krause, S.W.; Kiehl, M.G.; et al. Diagnosis of invasive fungal infections in haematological patients by combined use of galactomannan, 1,3-beta-D-glucan, Aspergillus PCR, multifungal DNA-microarray, and Aspergillus azole resistance PCRs in blood and bronchoalveolar lavage samples: Results of a prospective multicentre study. Clin. Microbiol. Infect. 2016, 22, 862-868.

70. Hoenigl, M.; Prattes, J.; Spiess, B.; Wagner, J.; Prueller, F.; Raggam, R.B.; Posch, V.; Duettmann, W.; Wolfler, A.; Koidl, C.; et al. Performance of Galactomannan, Beta-D-Glucan, Aspergillus Lateral-Flow Device, Conventional Culture, and PCR Tests with Bronchoalveolar Lavage Fluid for Diagnosis of Invasive Pulmonary Aspergillosis. J. Clin. Microbiol. 2014, 52, 2039-2045. [CrossRef]

71. Jenks, J.D.; Salzer, H.J.F.; Hoenigl, M. Improving the rates of Aspergillus detection: An update on current diagnostic strategies. Expert Rev. Anti-Infect. Ther. 2018, 17, 39-50. [CrossRef]

72. Jenks, J.D.; Mehta, S.R.; Taplitz, R.; Aslam, S.; Reed, S.L.; Hoenigl, M. Point-of-care diagnosis of invasive aspergillosis in non-neutropenic patients: Aspergillus Galactomannan Lateral Flow Assay versus Aspergillus -specific Lateral Flow Device test in bronchoalveolar lavage. Mycoses 2019, 62, 230-236. [CrossRef]

73. Mercier, T.; Dunbar, A.; De Kort, E.; Schauwvlieghe, A.; Reynders, M.; Guldentops, E.; Blijlevens, N.M.A.; Vonk, A.G.; Rijnders, B.; Verweij, P.E.; et al. Lateral flow assays for diagnosing invasive pulmonary aspergillosis in adult hematology patients: A comparative multicenter study. Med. Mycol. 2019, 58, 444-452. [CrossRef] [PubMed] 
74. Jenks, J.D.; Prattes, J.; Frank, J.; Spiess, B.; Mehta, S.R.; Boch, T.; Buchheidt, D.; Hoenigl, M. Performance of the Bronchoalveolar Lavage Fluid Aspergillus Galactomannan Lateral Flow Assay with Cube Reader for Diagnosis of Invasive Pulmonary Aspergillosis: A Multicenter Cohort Study. Clin. Infect. Dis. 2020, ciaa1281. [CrossRef]

75. Jenks, J.D.; Hoenigl, M. Point-of-care diagnostics for invasive aspergillosis: Nearing the finish line. Expert Rev. Mol. Diagn. 2020, 2020,1-9. [CrossRef] [PubMed]

76. Fernández-Cruz, A.; Semiglia, M.A.; Guinea, J.; Martínez-Jiménez, M.D.C.; Escribano, P.; Kwon, M.; Rodríguez-Macías, G.; Chamorro-De-Vega, E.; Rodríguez-González, C.; Navarro, R.; et al. A retrospective cohort of invasive fusariosis in the era of antimould prophylaxis. Med. Mycol. 2019, 58, 300-309. [CrossRef] [PubMed]

77. Nucci, M.; Carlesse, F.; Cappellano, P.; Varon, A.G.; Seber, A.; Garnica, M.; Nouér, S.A.; Colombo, A.L. Earlier Diagnosis of Invasive Fusariosis with Aspergillus Serum Galactomannan Testing. PLoS ONE 2014, 9, e87784. [CrossRef] [PubMed]

78. White, P.L.; Wingard, J.R.; Bretagne, S.; Löffler, J.; Patterson, T.F.; Slavin, M.; Barnes, R.A.; Pappas, P.G.; Donnelly, J.P. Aspergillus Polymerase Chain Reaction: Systematic Review of Evidence for Clinical Use in Comparison With Antigen Testing. Clin. Infect. Dis. 2015, 61, 1293-1303. [CrossRef]

79. Arastehfar, A.; Carvalho, A.; Van De Veerdonk, F.L.; Jenks, J.D.; Koehler, P.; Krause, R.; Cornely, O.A.; Perlin, D.; Lass-Flörl, C.; Hoenigl, M. COVID-19 Associated Pulmonary Aspergillosis (CAPA)—From Immunology to Treatment. J. Fungi 2020, 6, 91. [CrossRef] [PubMed]

80. Hoenigl, M. Invasive Fungal Disease complicating COVID-19: When it rains it pours. Clin. Infect. Dis. 2020, ciaa1342. [CrossRef]

81. Egger, M.; Jenks, J.D.; Hoenigl, M.; Prattes, J. Blood Aspergillus PCR: The Good, the Bad, and the Ugly. J. Fungi 2020, 6, 18. [CrossRef]

82. Baldin, C.; Soliman, S.S.M.; Jeon, H.H.; Alkhazraji, S.; Gebremariam, T.; Gu, Y.; Bruno, V.M.; Cornely, O.A.; Leather, H.L.; Sugrue, M.W.; et al. PCR-Based Approach Targeting Mucorales-Specific Gene Family for Diagnosis of Mucormycosis. J. Clin. Microbiol. 2018, 56. [CrossRef]

83. Rocchi, S.; Scherer, E.; Mengoli, C.; Alanio, A.; Botterel, F.; Bougnoux, M.E.; Bretagne, S.; Cogliati, M.; Cornu, M.; Dalle, F.; et al. Interlaboratory evaluation of Mucorales PCR assays for testing serum specimens: A study by the fungal PCR Initiative and the Modimucor study group. Med. Mycol. 2020, myaa036. [CrossRef]

84. Springer, J.; Lackner, M.; Nachbaur, D.; Girschikofsky, M.; Risslegger, B.; Mutschlechner, W.; Fritz, J.; Heinz, W.J.; Einsele, H.; Ullmann, A.J.; et al. Prospective multicentre PCR-based Aspergillus DNA screening in high-risk patients with and without primary antifungal mould prophylaxis. Clin. Microbiol. Infect. 2016, 22, 80-86. [CrossRef]

85. Reinwald, M.; Hummel, M.; Kovalevskaya, E.; Spiess, B.; Heinz, W.J.; Vehreschild, J.J.; Schultheis, B.; Krause, S.W.; Claus, B.; Suedhoff, T.; et al. Therapy with antifungals decreases the diagnostic performance of PCR for diagnosing invasive aspergillosis in bronchoalveolar lavage samples of patients with haematological malignancies. J. Antimicrob. Chemother. 2012, 67, 2260-2267. [CrossRef]

86. Boch, T.; Reinwald, M.; Spiess, B.; Liebregts, T.; Schellongowski, P.; Meybohm, P.; Rath, P.-M.; Steinmann, J.; Trinkmann, F.; Britsch, S.; et al. Detection of invasive pulmonary aspergillosis in critically ill patients by combined use of conventional culture, galactomannan, 1-3-beta-D-glucan and Aspergillus specific nested polymerase chain reaction in a prospective pilot study. J. Crit. Care 2018, 47, 198-203. [CrossRef]

87. Rawlings, S.A.; Heldt, S.; Prattes, J.; Eigl, S.; Jenks, J.D.; Flick, H.; Rabensteiner, J.; Prüller, F.; Wölfler, A.; Neumeister, P.; et al. Using Interleukin 6 and 8 in Blood and Bronchoalveolar Lavage Fluid to Predict Survival in Hematological Malignancy Patients with Suspected Pulmonary Mold Infection. Front. Immunol. 2019, 10, 1798. [CrossRef]

88. Jenks, J.D.; Rawlings, S.A.; Garcia-Vidal, C.; Koehler, P.; Mercier, T.; Prattes, J.; Lass-Flörl, C.; Martín-Gómez, M.T.; Buchheidt, D.; Pagano, L.; et al. Immune Parameters for Diagnosis and Treatment Monitoring in Invasive Mold Infection. J. Fungi 2019, 5, 116. [CrossRef]

89. Heldt, S.; Eigl, S.; Prattes, J.; Flick, H.; Rabensteiner, J.; Prüller, F.; Niedrist, T.; Neumeister, P.; Wölfler, A.; Strohmaier, H.; et al. Levels of interleukin (IL)-6 and IL-8 are elevated in serum and bronchoalveolar lavage fluid of haematological patients with invasive pulmonary aspergillosis. Mycoses 2017, 60, 818-825. [CrossRef] 
90. Hoenigl, M.; Orasch, T.; Faserl, K.; Prattes, J.; Loeffler, J.; Springer, J.; Gsaller, F.; Reischies, F.; Duettmann, W.; Raggam, R.B.; et al. Triacetylfusarinine C: A urine biomarker for diagnosis of invasive aspergillosis. J. Infect. 2019, 78, 150-157. [CrossRef]

91. Orasch, T.; Prattes, J.; Faserl, K.; Eigl, S.; Düttmann, W.; Lindner, H.; Haas, H.; Hoenigl, M.; Orascha, T.; Prattesa, J. Bronchoalveolar lavage triacetylfusarinine C (TAFC) determination for diagnosis of invasive pulmonary aspergillosis in patients with hematological malignancies. J. Infect. 2017, 75, 370-373. [CrossRef]

92. Haas, H. Fungal siderophore metabolism with a focus on Aspergillus fumigatus. Nat. Prod. Rep. 2014, 31, 1266-1276. [CrossRef]

93. Koo, S.; Thomas, H.R.; Daniels, S.D.; Lynch, R.C.; Fortier, S.M.; Shea, M.M.; Rearden, P.; Comolli, J.C.; Baden, L.R.; Marty, F.M. A Breath Fungal Secondary Metabolite Signature to Diagnose Invasive Aspergillosis. Clin. Infect. Dis. 2014, 59, 1733-1740. [CrossRef]

94. Vidal-García, M.; Redrado, S.; Domingo, M.P.; Marquina, P.; Colmenarejo, C.; Meis, J.F.; Rezusta, A.; Pardo, J.; Gálvez, E.M. Production of the Invasive Aspergillosis Biomarker Bis(methylthio)gliotoxin Within the Genus Aspergillus: In Vitro and in Vivo Metabolite Quantification and Genomic Analysis. Front. Microbiol. 2018, 9, 1246. [CrossRef]

95. Normand, A.-C.; Becker, P.; Gabriel, F.; Cassagne, C.; Accoceberry, I.; Gari-Toussaint, M.; Hasseine, L.; De Geyter, D.; Pierard, D.; Surmont, I.; et al. Validation of a New Web Application for Identification of Fungi by Use of Matrix-Assisted Laser Desorption Ionization-Time of Flight Mass Spectrometry. J. Clin. Microbiol. 2017, 55, 2661-2670. [CrossRef]

96. Thompson, G.R.; Barker, B.M.; Wiederhold, N.P. Large-Scale Evaluation of In Vitro Amphotericin B, Triazole, and Echinocandin Activity against Coccidioides Species from U.S. Institutions. Antimicrob. Agents Chemother. 2017, 61, e02634-16. [CrossRef]

97. Brilhante, R.S.N.; Guedes, G.M.D.M.; Da Silva, M.L.Q.; Castelo-Branco, D.S.; Cordeiro, R.D.A.; Sidrim, J.J.C.; Rocha, M.F.G. A proposal for antifungal epidemiological cut-off values against Histoplasma capsulatum var. capsulatum based on the susceptibility of isolates from HIV-infected patients with disseminated histoplasmosis in Northeast Brazil. Int. J. Antimicrob. Agents 2018, 52, 272-277. [CrossRef]

98. Rodrigues, A.M.; De Hoog, G.S.; Pires, D.D.C.; Brilhante, R.S.N.; Sidrim,J.J.D.C.; Rocha, M.F.G.; Colombo, A.L.; De Camargo, Z.P. Genetic diversity and antifungal susceptibility profiles in causative agents of sporotrichosis. BMC Infect. Dis. 2014, 14, 219. [CrossRef]

99. Borba-Santos, L.P.; Rodrigues, A.M.; Gagini, T.B.; Fernandes, G.F.; Castro, R.; De Camargo, Z.P.; Nucci, M.; Lopes-Bezerra, L.M.; Ishida, K.; Rozental, S. Susceptibility of Sporothrix brasiliensis isolates to amphotericin B, azoles, and terbinafine. Med. Mycol. 2014, 53, 178-188. [CrossRef]

100. McHardy, I.H.; Dinh, B.-T.N.; Waldman, S.; Stewart, E.; Bays, D.; Pappagianis, D.; Thompson, G.R. Coccidioidomycosis Complement Fixation Titer Trends in the Age of Antifungals. J. Clin. Microbiol. 2018, 56, e01318-18. [CrossRef]

101. Turner, S.; Kaufman, L.; Jalbert, M. Diagnostic assessment of an enzyme-linked immunosorbent assay for human and canine blastomycosis. J. Clin. Microbiol. 1986, 23, 294-297. [CrossRef]

102. Klein, B.S.; Kuritsky, J.N.; Chappell, W.A.; Kaufman, L.; Green, J.; Davies, S.F.; Williams, J.E.; Sarosi, G.A. Comparison of the Enzyme Immunoassay, Immunodiffusion, and Complement Fixation Tests in Detecting Antibody in Human Serum to the A Antigen ofBlastomyces dermatitidis1-3. Am. Rev. Respir. Dis. 1986, 133, 144-148. [CrossRef]

103. Klein, B.S.; Vergeront, J.M.; Kaufman, L.; Bradsher, R.W.; Kumar, U.N.; Mathai, G.; Varkey, B.; Davis, J.P. Serological Tests for Blastomycosis: Assessments During a Large Point-Source Outbreak in Wisconsin. J. Infect. Dis. 1987, 155, 262-268. [CrossRef]

104. Leimann, B.C.Q.; Pizzini, C.V.; Muniz, M.D.M.; Albuquerque, P.C.; Monteiro, P.C.F.; Reis, R.S.; Almeida-Paes, R.; Lazéra, M.D.S.; Wanke, B.; Pérez, M.A.; et al. Histoplasmosis in a Brazilian center: Clinical forms and laboratory tests. Rev. Iberoam. Micol. 2005, 22.

105. Falci, D.R.; Hoffmann, E.R.; Paskulin, D.D.; Pasqualotto, A.C. Progressive disseminated histoplasmosis: A systematic review on the performance of non-culture-based diagnostic tests. Braz. J. Infect. Dis. 2017, 21, 7-11. [CrossRef]

106. Dantas, K.; De Freitas, R.S.; Da Silva, M.V.; Criado, P.R.; Luiz, O.D.C.; Vicentini, A.P. Comparison of diagnostic methods to detect Histoplasma capsulatum in serum and blood samples from AIDS patients. PLoS ONE 2018, 13, e0190408. [CrossRef] [PubMed] 
107. Caceres, D.H.; Knuth, M.; Derado, G.; Lindsley, M.D. Diagnosis of Progressive Disseminated Histoplasmosis in Advanced HIV: A Meta-Analysis of Assay Analytical Performance. J. Fungi 2019, 5, 76. [CrossRef]

108. De Camargo, Z.P. Serology of paracoccidioidomycosis. Mycopathologia 2008, 165, 289-302. [CrossRef]

109. Perenha-Viana, M.C.Z.; Gonzales, I.A.A.; Brockelt, S.R.; Machado, L.N.C.; Svidzinski, T.I. Serological Diagnosis of Paracoccidioidomycosis through a Western Blot Technique. Clin. Vaccine Immunol. 2012, 19, 616-619. [CrossRef]

110. Pereira, E.F.; Gegembauer, G.; Chang, M.R.; De Camargo, Z.P.; Nunes, T.F.; Ribeiro, S.M.; De Carvalho, L.R.; Maldonado, B.M.; Mendes, R.P.; Paniago, A.M.M. Comparison of clinico-epidemiological and radiological features in paracoccidioidomycosis patients regarding serological classification using antigens from Paracoccidioides brasiliensis complex and Paracoccidioides lutzii. PLoS Negl. Trop. Dis. 2020, 14, e0008485. [CrossRef]

111. Wang, Y.-F.; Cai, J.-P.; Wang, Y.-D.; Dong, H.; Hao, W.; Jiang, L.-X.; Long, J.; Chan, C.; Woo, P.C.Y.; Lau, S.K.P.; et al. Immunoassays Based on Penicillium marneffei Mp1p Derived from Pichia pastoris Expression System for Diagnosis of Penicilliosis. PLoS ONE 2011, 6, e28796. [CrossRef]

112. Cao, L.; Chen, D.-L.; Lee, C.; Chan, C.-M.; Chan, K.-M.; Vanittanakom, N.; Tsang, D.N.C.; Yuen, K.-Y. Detection of Specific Antibodies to an Antigenic Mannoprotein for Diagnosis of Penicillium marneffeiPenicilliosis. J. Clin. Microbiol. 1998, 36, 3028-3031. [CrossRef]

113. Jenks, J.D.; Reed, S.L.; Hoenigl, M. Risk factors and outcomes of culture-proven acute Coccidioides spp. infection in San Diego, California, United States. Mycoses 2020, 63, 553-557. [CrossRef] [PubMed]

114. Buitrago, M.J.; Bernal-Martínez, L.; Castelli, M.V.; Rodriguez-Tudela, J.L.; Cuenca-Estrella, M. Histoplasmosis and Paracoccidioidomycosis in a Non-Endemic Area: A Review of Cases and Diagnosis. J. Travel Med. 2011, 18, 26-33. [CrossRef] [PubMed]

115. Durkin, M.; Witt, J.; Lemonte, A.; Wheat, B.; Connolly, P. Antigen Assay with the Potential To Aid in Diagnosis of Blastomycosis. J. Clin. Microbiol. 2004, 42, 4873-4875. [CrossRef] [PubMed]

116. Bariola, J.R.; Hage, C.A.; Durkin, M.; Bensadoun, E.; Gubbins, P.O.; Wheat, L.J.; Bradsher, R.W. Detection of Blastomyces dermatitidis antigen in patients with newly diagnosed blastomycosis. Diagn. Microbiol. Infect. Dis. 2011, 69, 187-191. [CrossRef] [PubMed]

117. Connolly, P.A.; Hage, C.A.; Bariola, J.R.; Bensadoun, E.; Rodgers, M.; Bradsher, R.W.; Wheat, L.J. Blastomyces dermatitidis Antigen Detection by Quantitative Enzyme Immunoassay. Clin. Vaccine Immunol. 2011, 19, 53-56. [CrossRef] [PubMed]

118. Frost, H.M.; Novicki, T.J. Blastomyces Antigen Detection for Diagnosis and Management of Blastomycosis. J. Clin. Microbiol. 2015, 53, 3660-3662. [CrossRef]

119. Wheat, J.; Wheat, H.; Connolly, P.; Kleiman, M.; Supparatpinyo, K.; Nelson, K.; Bradsher, R.; Restrepo, A. Cross-reactivity in Histoplasma capsulatum variety capsulatum antigen assays of urine samples from patients with endemic mycoses. Clin. Infect. Dis. 1997, 24, 1169-1171. [CrossRef]

120. Durkin, M.; Connolly, P.; Kuberski, T.; Myers, R.; Kubak, B.M.; Bruckner, D.; Pegues, D.; Wheat, L.J. Diagnosis of Coccidioidomycosis with Use of theCoccidioidesAntigen Enzyme Immunoassay. Clin. Infect. Dis. 2008, 47, e69-e73. [CrossRef]

121. Libert, D.; Procop, G.W.; Ansari, M.Q. Histoplasma Urinary Antigen Testing Obviates the Need for Coincident Serum Antigen Testing. Am. J. Clin. Pathol. 2018, 149, 362-368. [CrossRef]

122. Wheat, L.J.; Connolly-Stringfield, P.; Kohler, R.B.; Frame, P.T.; Gupta, M.R. Histoplasma capsulatum polysaccharide antigen detection in diagnosis and management of disseminated histoplasmosis in patients with acquired immunodeficiency syndrome. Am. J. Med. 1989, 87.

123. Moreira, A.L.E.; Oliveira, M.A.P.; Silva, L.O.S.; Inácio, M.M.; Bailão, A.M.; Parente-Rocha, J.A.; Cruz-Leite, V.R.M.; Paccez, J.D.; Soares, C.M.D.A.; Weber, S.S.; et al. Immunoproteomic Approach of Extracellular Antigens From Paracoccidioides Species Reveals Exclusive B-Cell Epitopes. Front. Microbiol. 2020, 10, 2968. [CrossRef] [PubMed]

124. Thu, N.; Chan, J.; Hien, H.; Tung, N.; Thanh, N.; Day, J.; Chau, N.; Thwaites, G.E.; Woo, P.; Yuen, K.; et al. Clinical Performance of the Mp1p Immunoassay for Rapid Diagnosis of Talaromyces marneffei Infection. In Proceedings of the Conference on Retroviruses and Opportunistic Infections (CROI), Seattle, WA, USA, 13-16 February 2017. 
125. Bialek, R.; Cirera, A.C.; Herrmann, T.; Aepinus, C.; Shearn-Bochsler, V.I.; Legendre, A.M. Nested PCR Assays for Detection of Blastomyces dermatitidis DNA in Paraffin-Embedded Canine Tissue. J. Clin. Microbiol. 2003, 41, 205-208. [CrossRef] [PubMed]

126. Sidamonidze, K.; Peck, M.K.; Perez, M.; Baumgardner, D.; Smith, G.; Chaturvedi, V.; Chaturvedi, S. Real-Time PCR Assay for Identification of Blastomyces dermatitidis in Culture and in Tissue. J. Clin. Microbiol. 2012, 50, 1783-1786. [CrossRef] [PubMed]

127. Babady, N.E.; Buckwalter, S.P.; Hall, L.; Le Febre, K.M.; Binnicker, M.J.; Wengenack, N.L. Detection of Blastomyces dermatitidis and Histoplasma capsulatum from Culture Isolates and Clinical Specimens by Use of Real-Time PCR. J. Clin. Microbiol. 2011, 49, 3204-3208. [CrossRef] [PubMed]

128. Vucicevic, D.; Blair, J.E.; Binnicker, M.J.; McCullough, A.E.; Kusne, S.; Vikram, H.R.; Parish, J.M.; Wengenack, N.L. The Utility of Coccidioides Polymerase Chain Reaction Testing in the Clinical Setting. Mycopathologia 2010, 170, 345-351. [CrossRef] [PubMed]

129. Thompson, G.R., III; Sharma, S.; Bays, D.J.; Pruitt, R.; Engelthaler, D.M.; Bowers, J.; Driebe, E.M.; Davis, M.; Libke, R.; Cohen, S.H.; et al. Coccidioidomycosis: Adenosine deaminase levels, serologic parameters, culture results, and polymerase chain reaction testing in pleural fluid. Chest 2013, 143, 776-781. [CrossRef]

130. Vasconcellos, I.C.D.S.; Lana, D.F.D.; Pasqualotto, A.C. The Role of Molecular Tests in the Diagnosis of Disseminated Histoplasmosis. J. Fungi 2019, 6, 1. [CrossRef]

131. Rocha-Silva, F.; De Figueiredo, S.M.; La Santrer, E.F.R.; Machado, A.S.; Fernandes, B.; Assunção, C.B.; Góes, A.M.; Caligiorne, R.B. Paracoccidioidomycosis: Detection of Paracoccidioides brasiliensis' genome in biological samples by quantitative chain reaction polymerase (qPCR). Microb. Pathog. 2018, 121, 359-362. [CrossRef]

132. Liu, X.; Zhang, Z.; Hou, B.; Wang, D.; Sun, T.; Li, F.; Wang, H.; Han, S. Rapid identification ofSporothrix schenckiiin biopsy tissue by PCR. J. Eur. Acad. Dermatol. Venereol. 2012, 27, 1491-1497. [CrossRef]

133. Hu, S.; Chung, W.-H.; Hung, S.-I.; Ho, H.-C.; Wang, Z.-W.; Chen, C.-H.; Lu, S.-C.; Kuo, T.-T.; Hong, H.-S. Detection of Sporothrix schenckii in Clinical Samples by a Nested PCR Assay. J. Clin. Microbiol. 2003, 41, 1414-1418. [CrossRef]

134. Bernardes-Engemann, A.R.; Barros, M.D.L.; Zeitune, T.; Russi, D.C.; Orofino-Costa, R.; Lopes-Bezerra, L.M. Validation of a serodiagnostic test for sporotrichosis: A follow-up study of patients related to the Rio de Janeiro zoonotic outbreak. Med. Mycol. 2014, 53, 28-33. [CrossRef]

135. Hien, H.T.A.; Thanh, T.T.; Thu, N.T.M.; Nguyen, A.; Thanh, N.T.; Lan, N.P.H.; Simmons, C.; Shikuma, C.; Chau, N.V.V.; Thwaites, G.E.; et al. Development and evaluation of a real-time polymerase chain reaction assay for the rapid detection of Talaromyces marneffei MP1 gene in human plasma. Mycoses 2016, 59, 773-780. [CrossRef] [PubMed]

136. Girouard, G.; Lachance, C.; Pelletier, R. Observations on (1-3)-beta-D-glucan detection as a diagnostic tool in endemic mycosis caused by Histoplasma or Blastomyces. J. Med. Microbiol. 2007, 56, 1001-1002. [CrossRef] [PubMed]

137. Thompson, G.R., III; Bays, D.J.; Johnson, S.M.; Cohen, S.H.; Pappagianis, D.; Finkelman, M.A. Serum (1->3)-beta-D-glucan measurement in coccidioidomycosis. J. Clin. Microbiol. 2012, 50, 3060-3062. [CrossRef] [PubMed]

Publisher's Note: MDPI stays neutral with regard to jurisdictional claims in published maps and institutional affiliations.

(C) 2020 by the authors. Licensee MDPI, Basel, Switzerland. This article is an open access article distributed under the terms and conditions of the Creative Commons Attribution (CC BY) license (http://creativecommons.org/licenses/by/4.0/). 